\title{
Penerapan Fuctional Testing pada Uji Kelayakan Aplikasi Mobile Smart Malnutrition Detection
}

\author{
Feasibility Test for Smart Malnutrition Detection Application \\ Using Functional Testing
}

\author{
Rani Purbaningtyas \\ Universitas Bhayangkara Surabaya; Jl. Ahmad Yani no. 114 Surabaya, (0331) 8285602 \\ Fakultas Teknik, Universitas Bhayangkara Surabaya, Surabaya \\ E-mail: raniubhara@gmail.com
}

\begin{abstract}
Abstrak
Aplikasi Smart Malnutrition Detection merupakan aplikasi berbasis mobile yang dapat membantu deteksi dini secara mandiri terhadap status gizi setiap individu serta memberikan rekomendasi asupan gizi harian yang didasarkan pada kebutuhan kalori harian pengguna. Sebelum aplikasi Smart Malnutrition Detection ini digunakan secara luas, maka perlu dilakukan pengujian untuk menentukan tingkat kelayakan dari sistem yang telah dibuat. Pengujian sistem dilakukan secara functional testing dengan menerapkan tujuh teknik pengujian yaitu unit testing, system testing, error handling testing, performance testing, installation dan load testing, user help testing dan validity testing. Hasil pengujian menunjukkan bahwa aplikasi Smart Malnutrition Detection ini sudah layak uji secara functional testing sehingga dapat digunakan secara luas.
\end{abstract}

Kata kunci: aplikasi mobile, malnutrisi, functional testing

\begin{abstract}
Smart Malnutrition Detection is a mobile application to give early detection of nutrient and provide a suggestion for daily nutrition intake based on daily calorie needs. Before this application widely used, we need to examine to determine the properness level of this system. System testing is done functionally by applying seven testing techniques, namely unit testing, system testing, error handling testing, performance testing, installation and load testing, user help testing and validity testing. The test results show that the Smart Malnutrition Detection application satisfies to functional testing so that it can be used widely.
\end{abstract}

Keywords: mobile application, malnutrition, functional testing

\section{PENDAHULUAN}

Aplikasi Smart Malnutrition Detection merupakan aplikasi berbasis mobile yang dapat membantu deteksi dini secara mandiri terhadap status gizi setiap individu serta memberikan rekomendasi asupan gizi harian yang didasarkan pada kebutuhan kalori harian pengguna [1]. Aplikasi ini sangat bermanfaat digunakan untuk deteksi dini malnutrisi karena dampak yang terjadi akibat malnutrisi sangat merugikan. Beberapa dampak dari malnutrisi yang bisa terjadi khususnya pada masa tumbuh kembang anak diantaranya adalah perkembangan otak menjadi lambat, ketidakmampuan tubuh melawan infeksi, anemia, gangguan pertumbuhan, kekurangan energi, protein dan mikronutrien [2]. Sehingga dirasa perlu untuk mengembangkan sebuah sistem yang mampu membantu deteksi dini kondisi gizi individu secara mandiri untuk meminimalkan terjadinya malnutrisi. 
Kondisi malnutrisi dapat dicegah dan ditangani dengan perbaikan asupan gizi. Pada umumnya, individu yang berkeinginan untuk memperbaiki status gizinya akan menemui konsultan gizi untuk mendapatkan saran dan rekomendasi asupan gizi yang tepat. Namun terkadang, dengan beragam alasan, individu malas untuk melakukan hal tersebut. Aplikasi Smart Malnutrition Detection hadir agar dapat membantu masyarakat untuk melakukan deteksi dini secara mandiri terhadap status gizi setiap individu. Hal ini bermanfaat untuk mencegah bahkan membantu penanganan kondisi malnutrisi yang terjadi di masyarakat. Sebelumnya juga pernah ada penelitian yang mengembangkan aplikasi untuk menentukan status gizi [3]. Namun aplikasi ini hanya mampu menentukan apakah individu termasuk dalam kategori kurus, ideal atau kelebihan berat badan. Sementara pada aplikasi mobile Smart Malnutrition Detection ini tidak hanya mampu membantu menentukan status gizi seseorang namun juga dapat memberikan rekomendasi asupan gizi yang dibutuhkan setiap individu berdasarkan kondisi fisiknya agar tidak mengalami kondisi malnutrisi. Rekomendasi asupan gizi yang diberikan pun juga mengacu pada standar Angka Kecukupan Gizi (AKG) yang telah ditetapkan oleh pemerintah. Beberapa aplikasi yang ditujukan untuk rekomendasi asupan gizi juga pernah dikembangkan sebelumnya. Diantaranya adalah aplikasi rekomendasi gizi yang dikhususkan bagi balita [4] dan rekomendasi kebutuhan gizi bagi lansia [5]. Sementara aplikasi Smart Malnutrition Detection tidak menyasar pada kategori usia tertentu sehingga target penggunanya lebih luas.

Sebelum aplikasi Smart Malnutrition Detection ini digunakan secara luas, maka perlu dilakukan pengujian untuk menentukan tingkat kelayakan dari sistem yang telah dibuat. Pengujian sistem dilakukan secara black box testing dari sisi functional testing. Functional testing adalah salah satu jenis pengujian black box testing yang menguji fungsionalitas dari setiap modul yang ada. Functional testing bertujuan untuk memastikan bahwa keseluruhan modul yang ada berjalan dengan baik. Pada penelitian ini teknik pengujian yang diterapkan meliputi 7 macam yaitu unit testing, system testing, error handling testing, performance testing, installation dan load testing, user help testing serta validity testing.

\section{METODE PENELITIAN}

Pengujian sistem adalah tahapan proses yang dilakukan untuk memastikan bahwa seluruh kebutuhan perangkat lunak dan perangkat keras telah terpenuhi. Sehingga dapat dilakukan perbaikan agar sistem dapat dimanfaatkan secara maksimal sesuai dengan tujuan pembuatan sistem [6]. Pengujian sistem dapat dilakukan secara white box testing maupun black box testing [7]. Pengujian secara white box testing yaitu menguji perangkat lunak dari segi desain dan kode program apakah mampu menghasilkan fungsi-fungsi, masukan dan keluaran yang sesuai dengan spesifikasi yang dibutuhkan. Contohnya: menguji alur dengan menelusuri pengulangan (looping) pada logika pemrograman [8]. Pengujian secara black box testing adalah menguji perangkat lunak dari segi spesifikasi fungsional tanpa menguji desain dan kode program. Pengujian ini dimaksudkan untuk mengetahui apakah fungsi-fungsi, masukan dan keluaran dari perangkat lunak telah sesuai dengan spesifikasi yang dibutuhkan [9].

Beberapa teknik pengujian yang termasuk dalam black box testing yaitu usability testing [10], functional testing [11], equivalence partitioning, boundary value analysis, cause effect graph, random data selection, feature test [12]. Penelitian ini bertujuan untuk menguji kelayakan dari aplikasi Smart Malnutrition Detection dari sisi functional testing. Pada penelitian ini teknik pengujian yang diterapkan meliputi 7 macam yaitu unit testing, system testing, error handling testing, performance testing, installation dan load testing, user help testing serta validity testing. Tahapan pelaksanaan pengujian digambarkan dalam flowchart sebagai berikut: 


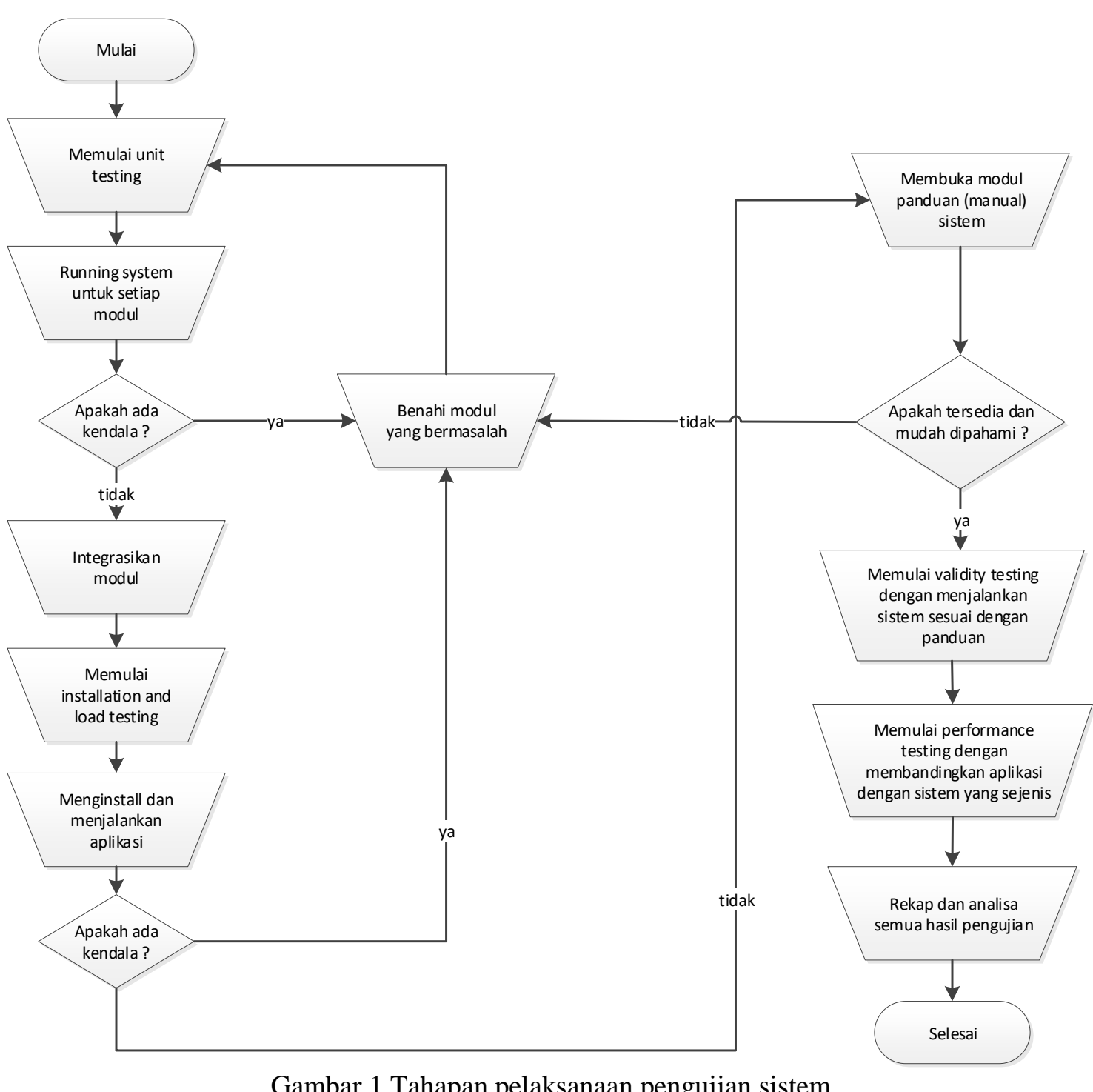

Tujuh (7) teknik pengujian dilakukan secara terurut mulai dari teknik unit testing. Unit testing dilakukan dengan cara menjalankan modul-modul yang terdapat pada aplikasi Smart Malnutrition Detection secara terpisah dan memastikan bahwa setiap modul tersebut dapat berjalan dengan baik dan sesuai dengan tujuan pembuatan masing-masing modul tersebut. Apabila dalam tahap pengujian ditemukan kendala, maka akan dilakukan perbaikan terhadap modul tersebut dan dilakukan pengujian unit testing kembali. Bilamana semua modul dapat berjalan dengan baik, maka keseluruhan modul yang ada siap untuk diintegrasikan. Dan hal ini menunjukkan bahwa secara unit testing, aplikasi ini telah memenuhi syarat.

Selanjutnya pengguna diminta untuk melakukan instalasi dan menjalankan aplikasi ini pada perangkat mobile phone yang dimiliki. Bilamana pada saar proses instalasi ada kendala, maka akan dilakukan perbaikan terlebih dahulu, diintegrasikan ulang dan mengulang kembali teknik pengujian installation and load testing kembali. Apabila aplikasi telah berhasil diinstal dan dijalankan oleh pengguna, maka secara teknik pengujian installation and load testing aplikasi ini juga telah memenuhi syarat.

Sebelum menjalankan modul-modul inti yang ada, pengguna diminta untuk membuka modul help sebagai panduan penggunaan sistem. Langkah ini dilakukan sebagai wujud dari teknik pengujian user help testing. Dimana pengujian dengan teknik ini bertujuan untuk menguji apakah pada aplikasi ini telah dilengkapi dengan panduan (manual) bagi pengguna 
untuk memudahkan penggunaan sistem. Bila tersedia dan panduan tersebut mudah dipahami oleh pengguna, maka secara user help testing, aplikasi ini telah memenuhi syarat.

Selanjutnya pengguna akan menjalankan aplikasi mulai dari modul awal hingga modul akhir sesuai dengan panduan. Hal ini dilakukan untuk mengetahui apakah akan terjadi crash (konflik) antar modul apabila dijalankan secara bersama-sama (diintegrasikan). Bilamana tidak terjadi crash, maka secara system testing aplikasi ini telah memenuhi syarat.

Selain itu hal ini juga bertujuan untuk mengetahui sejauh mana respon sistem terhadap semua interaksi yang diberikan oleh pengguna. Bilamana sistem dapat merespon dengan baik dan semua kelalaian yang mungkin dilakukan oleh pegguna dapat diantisipasi dengan baik, maka secara error handling testing aplikasi ini dinyatakan layak uji.

Dengan menjalankan keseluruhan modul yang tersedia dari awal hingga akhir sekaligus untuk mengetahui apakah luaran dari aplikasi ini telah sesuai dengan aturan yang berlaku. Bilamana semua luaran hasil perhitungan sistem sudah tepat, maka dapat dinyatakan bahwa aplikasi ini telah layak uji secara validity testing. Karena validity testing ditujukan untuk menguji tingkat akurasi data dan hasil perhitungan yang digunakan pada aplikasi ini.

Pengguna juga diminta untuk menjalankan beberapa aplikasi sejenis. Hal ini dilakukan untuk membandingkan keunggulan dan kelemahan dari masing-masing aplikasi. Bilamana aplikasi ini dianggap lebih unggul jika dibandingkan dengan aplikasi yang sejenis, maka secara performance testing aplikasi ini dinyatakan layak uji.

\section{HASIL DAN PEMBAHASAN}

Testing yang pertama dilakukan dengan menerapkan teknik unit testing, yaitu pengujian untuk setiap modul yang terdapat pada aplikasi Smart Malnutrition Detection untuk mengetahui apakah modul sudah berjalan sesuai dengan tujuan pembuatan modul tersebut atau belum. Aplikasi ini memiliki 3 modul utama yaitu modul untuk menghitung nilai Indeks Massa Tubuh (IMT), modul untuk perhitungan kalori dan modul untuk rekomendasi menu gizi.

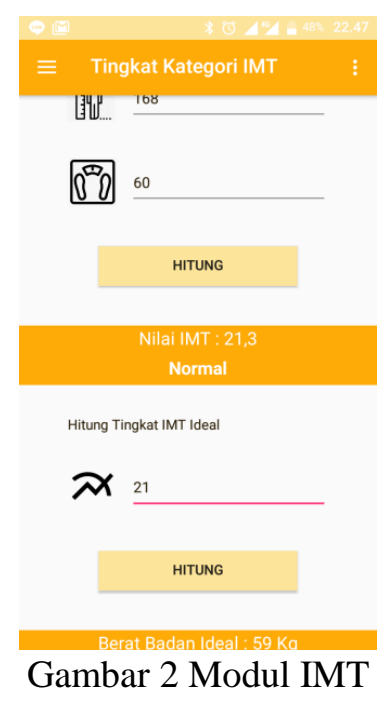

Pada gambar dua dapat dilihat bahwa bilamana pengguna memasukan keseluruhan data meliputi tinggi badan (dalam satuan centimeter) dan berat badan (dalam satuan kilogram) maka sistem akan menampilkan berapa nilai IMT pengguna saat ini. Sekaligus sistem juga akan menampilkan form input dialog untuk memasukkan nilai IMT yang ditargetkan oleh pengguna. 


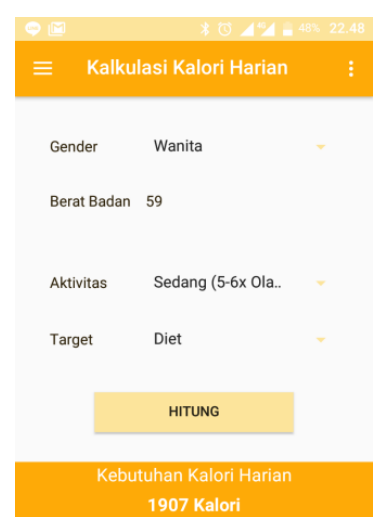

Gambar 3 Modul perhitungan kalori

Gambar tiga menunjukkan hasil perhitungan kalori yang dibutuhkan oleh pengguna. Perhitungan nilai kebutuhan kalori ini hanya akan ditampilkan bilamana pengguna telah memasukkan data jenis kelamin, usia, level aktivitas, dan target gizi yang diinginkan dengan pilihan yang disediakan meliputi normal, diet (menurunkan berat badan) atau menambah berat badan. Selain berdasarkan inputan data-data diatas, hasil perhitungan kalori ini juga dipengaruhi oleh inputan nilai IMT yang ditargetkan oleh pengguna.

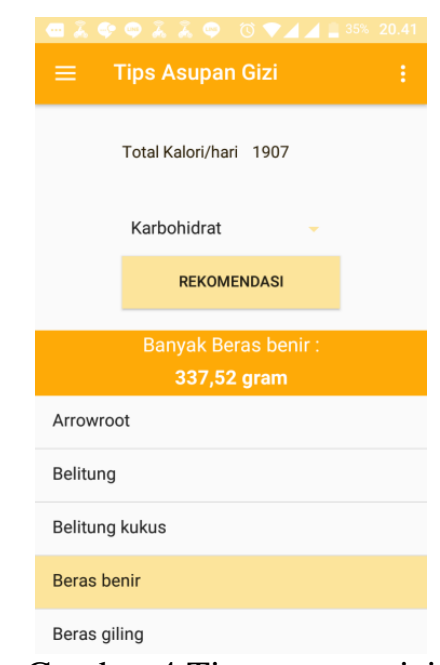

Gambar 4 Tips asupan gizi

Modul yang keempat ini merupakan modul untuk rekomendasi asupan gizi kepada pengguna yang telah terbagi menjadi 3 kelompok gizi utama yaitu karbohidrat, protein dan lemak. Pada modul ini untuk setiap kelompok gizi utama tersebut akan ditampilkan ragam pilihan jenis bahan makanan yang dapat dipilih sendiri oleh pengguna. Sistem akan menampilkan berapa besaran yang harus dikonsumsi oleh pengguna untuk setiap jenis bahan makanan tersebut dalam satuan gram.

Hasil pengujian dengan teknik unit testing menunjukkan bahwa ketiga modul dapat berjalan dengan baik sesuai dengan tujuan pembuatan dari tiap-tiap modul tersebut. Modul IMT mampu menampilkan nilai IMT pengguna saat ini dan nilai IMT target yang diinginkan oleh pengguna. Modul perhitungan kalori mampu menampilkan nilai kebutuhan kalori berdasarkan nilai target IMT yang diinginkan pengguna. Modul rekomendasi asupan gizi dapat menampilkan besaran nilai (dalam satuan gram) tiap jenis bahan makanan yang dapat dikonsumsi pengguna untuk setiap kelompok gizi utama.

Testing yang kedua yaitu dengan menerapkan system testing. Pengujian ini ditujukan untuk mencari adakah crash (konflik) antar modul setelah diintegrasikan. Hasil pengujian menunjukkan tidak ada masalah. Karena ketiga modul tersebut nantinya harus dijalankan secara 
berurutan yang diawali dengan modul IMT terlebih dahulu, dilanjutkan dengan modul perhitungan kalori dan terakhir adalah modul rekonmendasi asupan gizi. Bahkan bilamana pengguna mencoba untuk menjalankan modul aplikasi secara acak (tidak terurut), sistem akan menampilkan pesan untuk menjalankan modul pertama (modul IMT) terlebih dahulu. Sehingga secara system testing pada aplikasi Smart Malnutrition Detection ini tidak ditemukan masalah.

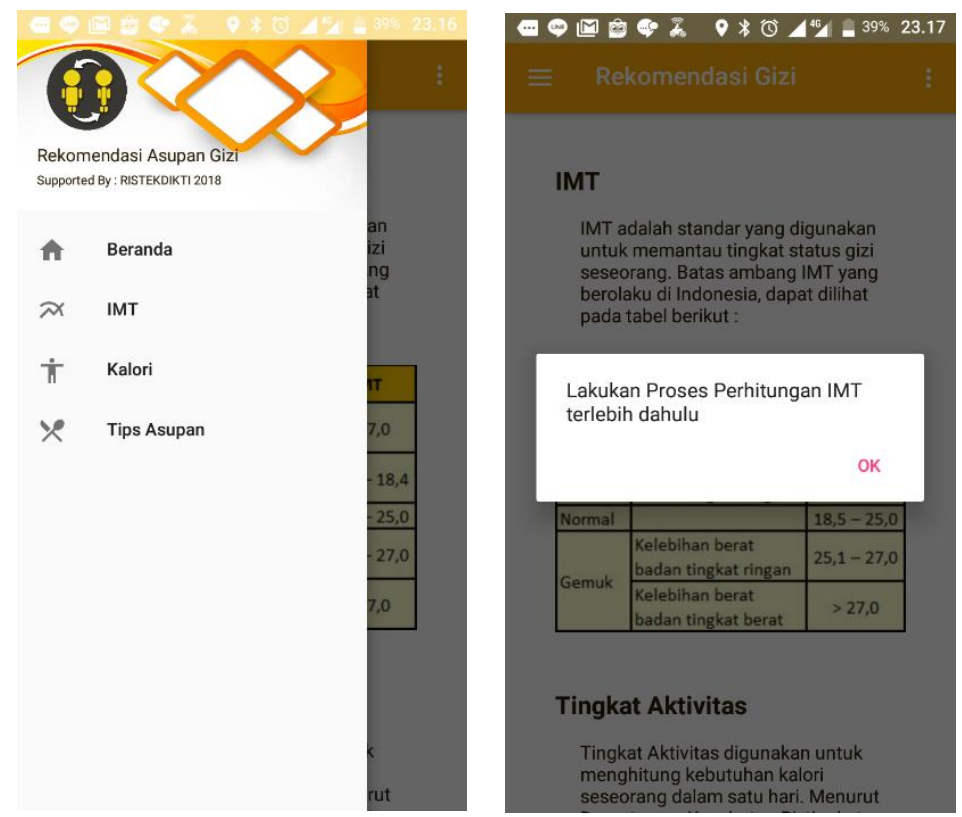

Gambar 5 Peringatan dari sistem apabila pengguna mencoba menjalankan modul secara acak

Testing ketiga yaitu pengujian secara error handling testing. Teknik pengujian ini ditujukan untuk melihat sejauh mana respon sistem dalam mengantisipasi kelalaian yang mungkin dilakukan oleh pengguna sistem. Pada modul IMT, form input dialog yang disediakan oleh sistem hanya berupa inputan angka-angka saja. Sehingga tidak mungkin pengguna akan melakukan kesalahan input data berupa data teks. Selain itu, angka yang bisa diinput dapat berupa bilangan bulat dan atau desimal. Namun untuk inputan angka dalam bentuk bilangan desimal menggunakan tanda baca "." bukan ",". Sehingga pada form input dialog, tanda baca "," diatur statusnya menjadi disable agar pengguna tidak melakukan kesalahan pada saat input data yang berupa bilangan desimal. 


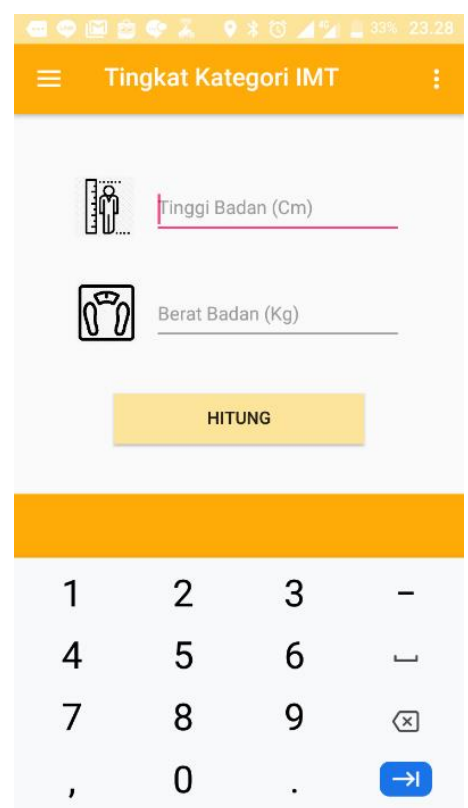

Gambar 6 Form input dialog pada modul IMT

Pada modul perhitungan kalori dan rekomendasi asupan gizi, data inputan ditampilkan dalam format combo box. Sehingga pengguna hanya tinggal memilih salah satu dari beberapa alternatif pilihan yang disediakan. Hal ini juga merupakan salah satu respon sistem untuk antisipasi kesalahan inputan data oleh pengguna bilamana pengguna harus mengetikkan datadata tersebut.

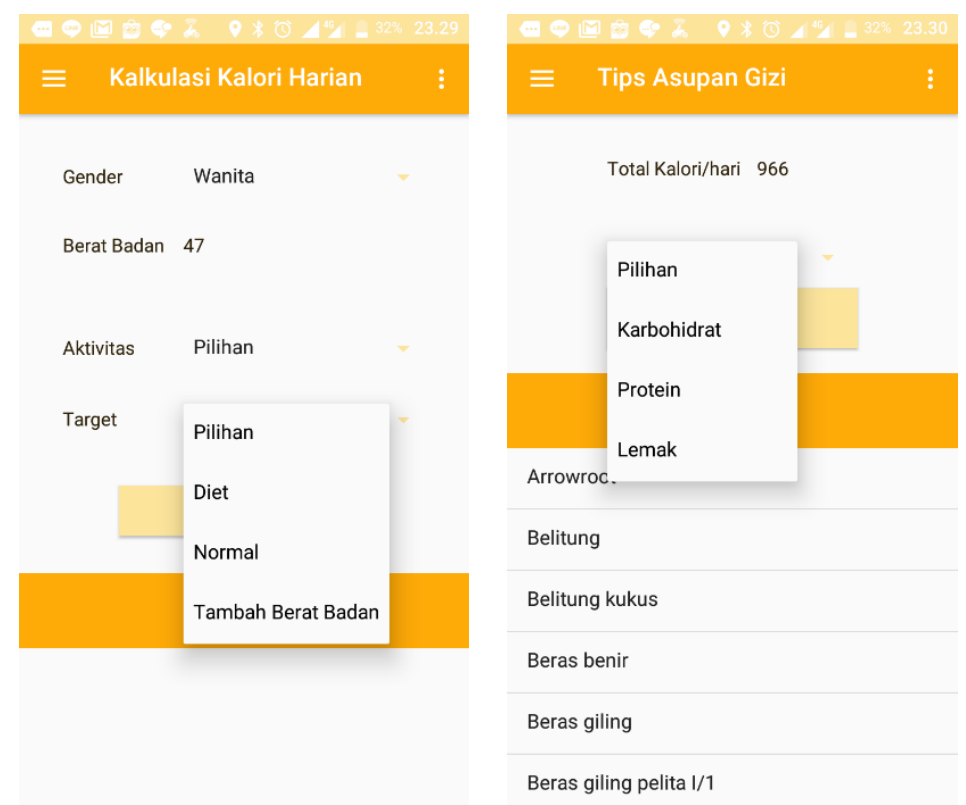

Gambar 7 Form input dialog dalam format combo box

Selain itu, seperti ditunjukkan pada gambar lima sebelumnya. Sistem akan menampilkan pesan peringatan apabila pengguna mencoba untuk menjalankan modul-modul pada aplikasi Smart Malnutrition Detection secara acak (tidak berurutan). Dan, apabila pengguna menjalankan aplikasi dimulai dari modul pertama (modul IMT) maka untuk modul selanjutnya (modul perhitungan kalori dan modul rekomendasi asupan gizi) akan ditampilkan (load) secara otomatis oleh sistem bilamana modul sebelumnya telah menampilkan data luaran. Berdasarkan 
hasil pengujian diatas, maka secara error handling testing aplikasi Smart Malnutrition Detection ini mampu memberikan respon yang baik untuk antisipasi terhadap kelalaian yang mungkin dilakukan oleh pengguna.

Pengujian selanjutnya yaitu menerapkan teknik performance testing. Pengujian dengan teknik ini akan membandingkan aplikasi Smart Malnutrition Detection dengan sistem sejenis sehingga nampak kelebihan dan kekurangan dari masing-masing sistem tersebut. Penelitian yang dilakukan oleh Bijak Jati Kusuma dan Tito Pinandita [3] berhasil membangun aplikasi mobile Perhitungan Indeks Massa Tubuh dan Berat Badan Ideal. Aplikasi yang dibuat dengan menggunakan Bahasa pemrograman J2ME ini digunakan untuk mengetahui indeks massa tubuh dan berat badan ideal yang diharapkan. Sehingga akan semakin mudah dan cepat dalam mengetahui apakah berat badannya tergolong kurang, normal lebih atau obesitas. Sedangkan perhitungan berat badan ideal, dapat digunakan untuk menghitung berapakah berat badan ideal yang sesuai dengan tinggi badan orang tersebut. Sehingga aplikasi ini hanya mampu untuk menentukan apakah seseorang tersebut tergolong ideal atau tidak berdasarkan nilai IMT yang diperoleh.

Penelitian yang dilakukan oleh Fitri, Onny Setyawati, dan Didik Rahadi S [4] serta Robertus Adi Nugroho dan Ridi Ferdiana [13] dimana masing-masing penelitian berhasil hingga mampu mengembangkan sistem rekomendasi menu makanan. Aplikasi-aplikasi yang dibuat ini sudah mampu menentukan menu bahan makanan sesuai dengan kebutuhan kalori pengguna. Namun kombinasi menu-menu tersebut bersifat statis dan terkadang pilihan jenis bahan makanan yang tertera tidak sesuai dengan selera pengguna.

Aplikasi Smart Malnutrition Detection tidak hanya mampu menilai apakah kondisi seseorang tersebut termasuk dalam kategori ideal atau tidak hanya berdasarkan nilai IMT. Namun aplikasi ini dapat digunakan oleh pengguna yang akan melakukan perbaikan kondisi malnutrisi dengan memasukkan nilai IMT target yang diinginkan. Aplikasi ini juga menghitung kebutuhan kalori harian pengguna tidak hanya berdasarkan nilai IMT saja namun juga berdasarkan data-data pendukung lainnya seperti jenis kelamin, usia, level aktifitas pengguna dan target perbaikan nutrisi pengguna apakah ditujukan untuk menambah atau mengurangi berat badan. Selain itu, rekomendasi asupan gizi yang dihasilkan oleh aplikasi ini bersifat dinamis dan juga dapat disesuaikan dengan selera pengguna. Sehingga dapat dilihat bahwa secara performance testing, aplikasi Smart Malnutrition Detection lebih unggul dibandingkan sistemsistem lain yang sejenis.

Pengujian yang kelima dengan menerapkan teknik installation dan load testing. Pengujian dengan teknik ini ditujukan untuk menguji apakah terdapat kendala pada pengguna pada saat melakukan proses instalasi dan menjalankan aplikasi ini pada perangkat mobile yang dimiliki oleh masing-masing pengguna. Proses pengujian dilakukan pada beberapa pengguna yang memiliki perangkat mobile phone dengan spesifikasi varian sistem operasi yang berbedabeda. Hasil pengujian menunjukkan tidak ada kendala yang berarti pada saat pengguna melakukan instalasi aplikasi Smart Malnutrition Detection ini. Selain itu, aplikasi ini juga tidak membutuhkan konsumsi memory yang besar karena hanya berukuran 7, 46 MB saja. Aplikasi juga dapat berjalan dengan baik dan lancar pada perangkat mobile phone yang memiliki spesifikasi minimum sistem operasi Android 4.0 (versi Ice Cream Sandwich).

Pengujian yang keenam dilakukan dengan menerapkan teknik pengujian user help testing. Pengujian ini ditujukan untuk menguji sejauh mana kelengkapan aplikasi Smart Malnutrition Detection ini apakah dibekali dengan manual (panduan) penggunaan aplikasi sehingga memudahkan pengguna pada saat menggunakan aplikasi ini. Hasil pengujian menunjukkan bahwa aplikasi Smart Malnutrition Detection ini tidak hanya dilengkapi dengan manual (panduan) penggunaan aplikasi saja namun juga dilengkapi dengan deskripsi singkat tentang beberapa istilah-istilah yang digunakan seperti IMT, penjelasan tentang pembagian kelompok tingkat aktivitas, dan besaran kebutuhan kalori yang berasal dari 3 kelompok gizi utama (karbohidrat, protein dan lemak). 


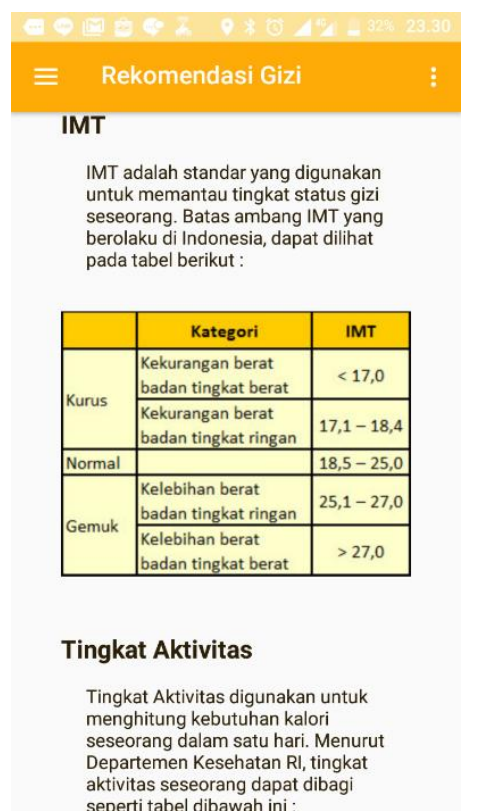

Gambar 8 Modul yang berisi tentang deskripsi istilah pada aplikasi Smart Malnutrition Detection

Pengujian yang terakhir dilakukan dengan dengan menerapkan teknik pengujian validity testing. Pengujian dengan teknik validity testing ditujukan untuk mengetahui apakah data-data dan formulasi perhitungan yang digunakan sudah sesuai dengan ketentuan yang berlaku. Hasil pengujian validity testing menunjukkan sebagai berikut :

1. Penentuan asupan gizi harian yang harus dikonsumsi oleh setiap individu akan memberikan hasil yang berbeda-beda karena dipengaruhi oleh faktor :

a. Tinggi badan (dalam satuan $\mathrm{cm}$ ) dan berat badan (dalam satuan kilogram)

b. Jenis kelamin

c. Tingkat aktifitas fisik harian dari individu tersebut

d. Target diet gizi dari individu yang bersangkutan apakah ingin mengurangi atau menambah berat badan

2. Sesuai dengan aturan yang ditetapkan oleh pemerintah [14], untuk perhitungan asupan gizi harian berdasarkan diet gizi, tahapan yang harus dilakukan adalah sebagai berikut :

a. Perhitungan nilai Indeks Massa Tubuh (IMT) dengan rumus perhitungan sebagai berikut:

$$
\mathrm{IMT}=\frac{\text { berat badan }(\mathrm{kg})}{\operatorname{tinggi} \text { badan }(\mathrm{m}) \times \operatorname{tinggi} \text { badan }(\mathrm{m})}
$$

Nilai IMT yang didapat nantinya akan dibandingkan dengan nilai batas ambang IMT yang berlaku di Indonesia untuk menentukan apakah orang tersebut termasuk dalam kategori kurus, normal atau gemuk [14].

b. Nilai IMT yang didapat pada tahap 1 dikombinasikan dengan data jenis kelamin dan tingkat aktifitas harian individu digunakan untuk menghitung nilai Energi Metabolisme Basal (EMB) atau Aktivitas Metabolisme Basal (AMB).

c. Nilai IMT dan nilai EMB/AMB akan digunakan untuk menentukan kebutuhan kalori harian individu.

d. Kebutuhan kalori harian individu nantinya akan dibagi kedalam kelompok gizi dengan ketentuan sebagai berikut [15] :

- Kebutuhan kalori dari kelompok karbohidrat sebesar 60\%. Karbohidrat didapatkan dari makanan golongan A.

Kebutuhan kalori dari kelompok protein sebesar 20\%. Protein didapatkan dari makanan golongan B, C, D, E, F, G, dan $\mathrm{H}$. 
- Kebutuhan kalori dari kelompok lemak sebesar 20\%. Lemak didapatkan dari makanan golongan I dan J.

e. Perhitungan jumlah konsumsi setiap bahan makanan (dalam satuan gram) digunakan rumus sebagai berikut :

$$
a=\frac{X}{C} \times 100(\text { gram }) \times \frac{100(\text { gram })}{B D D}
$$

Keterangan :

$\mathrm{a}=$ jumlah bahan makanan (gram)

$\mathrm{x}=$ jumlah zat gizi yang terkandung dalam bahan makanan

$\mathrm{BDD}=$ bagian yang dapat dimakan dari bahan makanan

$\mathrm{c}=$ jumlah zat gizi yang terkandung dalam $100 \mathrm{gr}$ bahan makanan

f. Untuk mengetahui konsistesi perhitungan nilai kalori yang terkandung dalam setiap bahan makanan digunakan rumus pembalik perhitungan kalori sebagai berikut :

$$
x=\frac{a}{B D D} x c
$$

Keterangan :

$\mathrm{x}=$ jumlah zat gizi yang terkandung dalam bahan makanan

$\mathrm{a}=$ jumlah bahan makanan (gram)

$\mathrm{BDD}=$ bagian yang dapat dimakan dari bahan makanan

$\mathrm{c}=$ jumlah zat gizi yang terkandung dalam $100 \mathrm{gr}$ bahan makanan

Berdasarkan hasil pengujian secara validity testing dapat dilihat bahwa setiap rumusan formulasi perhitungan yang diterapkan pada aplikasi Smart Malnutrition Detection ini sudah sesuai dengan ketentuan yang ditetapkan oleh pemerintah seperti tertuang pada Pedoman Gizi Seimbang : Pedoman Teknis Bagi Petugas Dalam Memberikan Penyuluhan Gizi Seimbang [14] dan Daftar Komposisi Zat Gizi Pangan Indonesia [15]. Sehingga dapat disimpulkan bahwa aplikasi Smart Malnutrition Detection ini telah memenuhi standar kelayakan validity testing.

Dari ketujuh teknik pengujian yang telah dilakukan untuk menguji tingkat kelayakan secara functional testing pada aplikasi Smart Malnutrition Detection ini digambarkan dalam tabel sebagai berikut :

Tabel 1 Hasil Pengujian Secara Functional Testing

\begin{tabular}{|l|l|c|c|}
\hline \multirow{2}{*}{ NO } & \multicolumn{1}{|c|}{$\begin{array}{c}\text { TEKNIK PENGUJIAN YANG } \\
\text { DITERAPKAN }\end{array}$} & \multicolumn{2}{c|}{$\begin{array}{c}\text { MEMENUHI SYARAT } \\
\text { KELAYAKAN }\end{array}$} \\
\cline { 3 - 4 } & \multicolumn{1}{|c|}{ YA (Y) } & TIDAK (T) \\
\hline 1. & Unit testing & $\sqrt{ }$ & \\
\hline 2. & System testing & $\sqrt{ }$ & \\
\hline 3. & Error handling testing & $\sqrt{ }$ & \\
\hline 4. & Performance testing & $\sqrt{ }$ & \\
\hline 5. & Installation dan load testing & $\sqrt{ }$ & \\
\hline 6. & User help testing & $\sqrt{ }$ & \\
\hline 7. & Validity testing & & \\
\hline
\end{tabular}

Sehinga dapat dinyatakan bahwa secara functional testing, aplikasi Smart Malnutrition Detection ini sudah layak uji dari dengan hasil uji sebagai berikut :

1. Setiap modul yang terdapat pada aplikasi Smart Malnutrition Detection dapat berjalan dengan baik dan lancar sesuai dengan tujuan pembuatan masing-masing modul tersebut. 
2. Setiap modul yang terdapat pada aplikasi Smart Malnutrition Detection bila diintegrasikan dapat berjalan dengan baik dan lancar serta tidak terjadi crash (konflik) antar modul-modul tersebut.

3. Aplikasi Smart Malnutrition Detection telah dilengkapi dengan respon sistem yang baik sebagai langkah antisipasi kelalaian yang mungkin dilakukan oleh pengguna.

4. Dibandingkan dengan aplikasi atau sistem yang sejenis, aplikasi Smart Malnutrition Detection ini memiliki keunggulan tidak hanya mampu menilai apakah kondisi seseorang tersebut termasuk dalam kategori ideal atau tidak hanya berdasarkan nilai IMT saja namun juga dapat digunakan oleh pengguna yang akan melakukan perbaikan kondisi malnutrisi dengan memasukkan nilai IMT target yang diinginkan. Aplikasi ini juga mampu menghitung kebutuhan kalori harian pengguna tidak hanya berdasarkan nilai IMT saja namun juga berdasarkan data-data pendukung lainnya seperti jenis kelamin, usia, level aktifitas pengguna dan target perbaikan nutrisi pengguna apakah ditujukan untuk menambah atau mengurangi berat badan. Rekomendasi asupan gizi yang dihasilkan oleh aplikasi ini bersifat dinamis dan juga dapat disesuaikan dengan selera pengguna

5. Aplikasi Smart Malnutrition Detection ini dapat berjalan tanpa kendala pada saat proses instalasi dan berjalan dengan baik pada perangkat mobile phone yang memiliki spesifikasi minimum sistem operasi Android 4.0 (versi Ice Cream Sandwich). Aplikasi ini juga hanya berukuran 7,46 MB sehingga tidak membutuhkan konsumsi memory yang cukup besar.

6. Aplikasi Smart Malnutrition Detection ini juga telah dilengkapi dengan manual (panduan) penggunaan aplikasi dan juga modul yang berisi deskripsi singkat tentang beberapa istilahistilah yang digunakan seperti IMT, penjelasan tentang pembagian kelompok tingkat aktivitas, dan besaran kebutuhan kalori yang berasal dari 3 kelompok gizi utama (karbohidrat, protein dan lemak).

7. Setiap rumusan formulasi perhitungan yang diterapkan pada aplikasi Smart Malnutrition Detection ini sudah sesuai dengan ketentuan yang ditetapkan oleh pemerintah [14]. Selain itu data-data jenis bahan makanan yang terdapat pada modul rekomendasi asupan gizi juga telah sesuai dengan ketentuan dari Dirjen Pembinaan Kesehatan Masyarakat Departemen Kesehatan Republik Indonesia [15].

\section{KESIMPULAN}

Aplikasi Smart Malnutrition Detection merupakan aplikasi berbasis mobile yang dapat membantu deteksi dini secara mandiri terhadap status gizi setiap individu serta memberikan rekomendasi asupan gizi harian yang didasarkan pada kebutuhan kalori harian pengguna. Rekomendasi asupan gizi yang diberikan mengacu pada standar Angka Kecukupan Gizi (AKG) yang telah ditetapkan oleh Departemen Kesehatan Republik Indonesia. Pengujian secara functional testing menunjukkan bahwa aplikasi ini layak uji sehingga dapat digunakan secara luas.

\section{SARAN}

Aplikasi Smart Malnutrition Detection ini sudah layak uji secara functional testing dan sesuai untuk diterapkan kepada pengguna yang memiliki kondisi kesehatan normal. Sehingga perlu dilakukan pengujian lebih lanjut untuk mengetahui apakah aplikasi ini juga layak uji jika diterapkan kepada pengguna dengan kondisi kesehatan khusus. 


\section{UCAPAN TERIMA KASIH}

Terima kasih kepada Direktorat Riset dan Pengabdian Masyarakat, Dirjen Penguatan Riset dan Pengembangan Kementerian Riset, Teknologi dan Pendidikan Tinggi Republik Indonesia yang telah bersedia untuk mendanai penelitian ini melalui Skema Penelitian Dosen Pemula Tahun Anggaran 2018 dengan judul "Aplikasi Smart Malnutrition Detection Sebagai Sarana Pendukung Pencegahan Dan Penanganan Anomali Kecukupan Gizi Pada Anak Dan Dewasa"

\section{DAFTAR PUSTAKA}

[1] Alim, Syariful, Arif Arizal, "Smart Malnutrition Detection : Deteksi Dini Kecukupan Gizi dan Rekomendasi Gizi Harian", Jurnal Informatika : Jurnal Pengembangan IT Politeknik Harapan Bersama Tegal, Vol. 3 No. 3 edisi September 2018.

[2] Zulaekah, Siti, Setiyo Purwanto, Listyani Hidayati, "Anemia Terhadap Pertumbuhan dan Perkembangan Anak Malnutrisi", Jurnal Kesehatan Masyarakat, Vol. 9 No. 2 edisi Januari 2014, hal. 106-114.

[3] Kusuma, Bijak Jati, Tito Pinandita, "Rancang Bangun Aplikasi Mobile Perhitungan Indeks Massa Tubuh dan Berat Badan Ideal”, Jurnal JUITA, Vol. 1 NO. 4 edisi Nopember 2011, hal. 157-168.

[4] Fitri, Onny Setyawati, Didik Rahadi S, "Rancang Bangun Aplikasi Mobile Perhitungan Indeks Massa Tubuh dan Berat Badan Ideal", Jurnal EECIS (Electrics, Electronics, Communications, Controls, Informatics, Systems) Universitas Brawijaya, Vol. 7 No. 2 edisi Desember 2013, hal. 119-124.

[5] Supono, Riza Adrianti, Karmilasari, Yuni Dwi Wulandari, "Aplikasi Penghitungan Kebutuhan Gizi Lansia Berbasis Smartphone Android", pada Prosiding Seminar Nasional Aplikasi Teknologi Informasi (SNATi) 2015, tanggal 6 Juni 2015, hal. I-11 - I-17.

[6] Nugroho, Atmoko, Basworo Ardi Pramono, "Aplikasi Mobile Augmented Reality Berbasis Vuforia dan Unity Pada Pengenalan Objek 3D Dengan Studi Kasus Gedung M Universitas Semarang”, Jurnal Transformatika Universitas Semarang, Vo. 14 No. 2 edisi Januari 2017, hal. 86-91. http://dx.doi.org/10.26623/transformatika.v14i2.442

[7] Al Fatta, Hanif, Robert Marco, "Analisis Pengembangan dan Perancangan Sistem Informasi Akademik Smart Berbasis Cloud Computing Pada Sekolah Menengah Umum Negeri (SMUN) di Daerah Istimewa Jogjakarta", Jurnal Telematika STMIK AMIKOM Purwokerto, Vol. 8 No. 2 edisi Agustus 2015, hal. 63-91

[8] Iskandar, Bagus, Agus Umar Hamdani, "Desain dan Pengujian Sistem Informasi Jasa Pengiriman Barang Studi Kasus : PT. XYZ" pada Prosiding Seminar Nasional Teknologi Informasi dan Multimedia (SEMNASTEKNOMEDIA) 2017 STMIK Amikom Yogyakarta, Vol. 5 No. 1 tanggal 4 Februari 2017, hal. 1.2-67 - 1.2-72

[9] Diah, Risti Ana, Umi Fadlillah, "Rancang Bangun Website dan E-Learning di TPQ AlFadhillah", Jurnal Khazanah Informatika : Jurnal Ilmiah Ilmu Komputer dan Informatika Universitas Muhammadiyah Surakarta, Vol. 1 No. 1 edisi Desember 2015, hal. 4043, https://doi.org/10.23917/khif.v1i1.1181

[10] Saputri, Intan Sandra Yatana, Mardiah Fadhli, Ibnu Surya, "Penerapan Metode UCD (User Centered Design) Pada E-Commerce Putri Intan Shop Berbasis Web", Jurnal Teknologi dan Sistem Informasi (TEKNOSI) Jurusan Sistem Informasi Universitas Andalas, Vol. 3 No. 2 edisi Agustus 2017, hal. 269-278, DOI : 10.25077/TEKNOSI.v3i2.2017.269-278

[11] Susanto, Erliyan Redy, Ferdi Ramadhan, "Rancang Bangun Aplikasi Bebasis Web Perizinan Praktik Tenaga Kesehatan Menggunakan Framework CodeIgniter Pada Dinas Kesehatan Kota Metro", Jurnal Teknokompak Universitas Teknokrat Indonesia, Vol. 11 No. 2 edisi Agustus 2017, hal. 55-60. 
[12] Aulianita, Rizki, "Penerapan Metode Waterfall Pada Perancangan Sistem Informasi Rumah Sakit Berbasis Website" pada Prosiding Simposium Nasional Ilmu Pengetahuan dan Teknologi (SIMNASIPTEK) 2017, tanggal 28 September 2017, hal. A-209 - A-217.

[13] Nugroho, Robertus Adi, Ridi Ferdiana, "Teknik Pemberian Rekomendasi Menu Makanan dengan Pendekatan Contextual Model dan Multi-Criteria Decission Making" pada Prosiding Seminar Internasional CITEE 2014, tanggal 7-8 Oktober 2014, hal. 88-94.

[14] Dirjen Bina Gizi dan Kesehatan Ibu dan Anak, Pedoman Gizi Seimbang : Pedoman Teknis Bagi Petugas Dalam Memberikan Penyuluhan Gizi Seimbang, Jakarta : Kementerian Kesehatan RI, 2014.

[15] Dirjen Pembinaan Kesehatan Masyarakat, Daftar Komposisi Zat Gizi Pangan Indonesia, Jakarta : Departemen Kesehatan, 1995. 